\title{
Effect of Micronutrients and Sea Weed Sap on Fruit Set, Yield and Quality of Mango (Mangifera indica L.) cv. Dashehari
}

\author{
Ravina Pawar* and A.K. Singh \\ Department of Horticulture, College of Agriculture, Govind Ballabh Pant University of \\ Agriculture and Technology, Pantnagar-263145 (Uttarakhand), India \\ *Corresponding author
}

\section{A B S T R A C T}

Keywords

Mango,

Micronutrients, Sea weed sap, Quality, yield

Article Info

Accepted:

04 November 2018

Available Online:

10 December 2018
The present investigation was carried out at GBPUA\&T, Pantnagar, U.S. Nagar, Uttarakhand during the year 2015 to study the effect of micronutrients and sea weed sap in mango cv. Dashehari. The investigation has shown that the application of RDF + foliar spray of $\mathrm{ZnSO}_{4} @ 0.4 \%+\mathrm{CuSO}_{4} @ 0.2 \%+$ Boric acid @ 0.2\% (2 sprays at just before flowering and marble stage) was found to be most effective for increasing number of fruits per panicle at pea and marble stage (9.67 and 4.58, respectively), yield plant ${ }^{-1}(271.51 \mathrm{~kg})$, yield ha ${ }^{-1}(27151 \mathrm{~kg})$, per cent increase in yield $(56.40 \%)$, TSS $\left(18.51^{\circ} \mathrm{B}\right)$, total sugar $(12.88 \%)$, ascorbic acid content $\left(43.62 \mathrm{mg} 100 \mathrm{~g}^{-1}\right.$ pulp) with reduced acidity $(0.149 \%)$. The higher fruit weight $(221.98 \mathrm{~g})$, fruit length $(10.87 \mathrm{~cm})$ and fruit width $(6.54 \mathrm{~cm})$ were observed with the application of RDF $+10 \%$ sea weed sap ( 2 sprays at panicle emergence and marble stage) $+\mathrm{ZnSO}_{4} @ 200 \mathrm{~g}+\mathrm{CuSO}_{4} @ 100 \mathrm{~g}+$ Boric acid @ $100 \mathrm{~g}$ (soil application). Thus, it is concluded that the basal application of recommended dose of fertilizer (RDF) with foliar spray of micronutrients may be helpful in upliftment of yield and quality of mango cv. Dashehari.

\section{Introduction}

Mango belongs to the genus Mangifera of the family Anacardiaceae, originated from IndoBurma (Myanmar) region (Vavilov, 1926; Popenoe, 1920). "King of fruits" having sweetness along with delightfully blended acidity holds a prominent place among the fruits of world and most important fruit crop in India having a great cultural, socioeconomic and religious significance. In India, the major mango growing states are Uttar Pradesh, Andhra Pradesh, Karnataka, Bihar, Maharashtra, Gujarat, Tamil Nadu, West Bengal and Orissa. As many as 111 countries of the world have been growing mango but India continues to be the largest mango producing country in the world. In India, it is grown on an area of 2.26 million hectares with annual production of 19.69 million tonnes having productivity of 8.70 metric tons per hectare (Anonymous, 2017).

Flowering, fruit setting, fruit development, fruit dropping, fruit ripening and fruit quality are governed by the availability of nutrients (Mengel and Kirky, 1987). The unbalanced fertilization, micronutrients deficiencies, poor management and inadequate cultural practices are mainly responsible for low productivity of 
mango and quality related issues at national level. Micronutrients have a potential to improve productivity and quality vis-a-vis bringing stability and sustainability in the production system particularly in respect of tropical and sub-tropical fruits. Along with micronutrients, amendment of seaweed liquid fertilizers (SLF) also enhances the soil health by improving moisture-holding capacity and by promoting the growth of beneficial soil microbes. They are considered as an organic farm input to be used under organic and integrated nutrient management farming as they are environmentally benign and safe for the health of animals and humans (Raverkar et al., 2016).

Therefore, considering the above facts and constraints, the present experiment was undertaken to study the effect of micronutrients and sea weed sap on fruit set, yield and quality of mango cv. Dashehari.

\section{Materials and Methods}

The field experiment was conducted at Horticulture Research Centreof Govind Ballabh Pant University of Agriculture \& Technology, Pantnagar $\left(29.5^{\circ} \mathrm{N}\right.$ latitude, 79.3 ${ }^{\circ} \mathrm{E}$ longitude and at an altitude of 243.84 meters above the mean sea level) Uttarakhand, India.The soil of the experimental plot has been classified as series II Patharchatta silty clay loam under the Order Mollisol (Deshpande et al., 1971). Soil is dark coloured, imperfectly drained with organic matter content in medium range. The soil has high cation exchange and water holding capacity and also contains about 90 per cent saturation. Twenty-year old bearing mango trees of cv. Dashehari, planted at spacing of 10 $\mathrm{m}$ x $10 \mathrm{~m}$, under uniform recommended management practices were selected. The experiment was laid out in a randomized block design with ten treatments replicated thrice with a unit of one plant per treatment per replication. The treatments were applied to individual tree as per the treatment details (Table 1).

The data were analysed according to the procedure of analysis for Randomized Block Design given by Cochran and Cox (1983). The significance of difference between pair of means was tested by the least significant difference (LSD) test at 5\% level of probability (Gomez and Gomez, 1984).

\section{Results and Discussion}

Effect of micronutrients and sea weed sap on number of fruit set per panicle (at pea stage and marble stage)

The data related to the fruit set per panicle at pea stage and at marble stage are presented in Table 2. All the treatments showed significant effect on number of fruit set per panicle at pea and marble stage as compared to control. The number of fruit set per panicle at pea stage was recorded maximum (9.67) in $\mathrm{T}_{5}[\mathrm{RDF}+$ foliar spray of $\mathrm{ZnSO}_{4} @ 0.4 \%+\mathrm{CuSO}_{4} @$ $0.2 \%$ + Boric acid@0.2\% (2 sprays at just before flowering and marble stage)] followed by $\mathrm{T}_{8}(8.98), \mathrm{T}_{10}(8.83)$ and $\mathrm{T}_{9}(8.75)$ and the minimum (6.75) was noted in $\mathrm{T}_{1}$ [Control (RDF)] followed by $\mathrm{T}_{6}(7.99), \mathrm{T}_{2}(8.00)$ and $\mathrm{T}_{3}$ (8.37). Number of fruit set at marble stage showed a significant effect of different combinations of inorganic fertilizers, micronutrients and sea weed sap during the study period. The higher number of fruit set at marble stage (4.58) was obtained with $\mathrm{T}_{5}$ followed by $\mathrm{T}_{8}(3.83), \mathrm{T}_{10}$ (3.75) and $\mathrm{T}_{9}(3.58)$, whereas, lower (1.91) was found with $T_{1}$. Increase in fruit set might be due to promoting effect of boron on cell division and multiplication as well as cell elongation of the plant.

Boron plays an important role in pollen germination and pollen tube growth which is associated with better pollination, fertilization and fruit setting (Thompson and Batjer, 1950). 
Similar findings were also observed by AbdEl Motty (2006) in citrus, Solimanzadeh et al., (2013) in pistachio nut and Mosa et al., (2015) in apple.

\section{Effect of micronutrients and sea weed sap on yield attributes}

\section{Fruit yield plant ${ }^{-1}$ and fruit yield hectare ${ }^{-1}$}

The data on fruit yield plant ${ }^{-1}$ and fruit yield hectare $^{-1}$ at the time of harvest are presented in Table 2. The fruit yield plant ${ }^{-1}$ was observed higher $\left(264.17 \mathrm{~kg}\right.$ plant $\left.^{-1}\right)$ with the application of $\mathrm{T}_{5}\left[\mathrm{RDF}+\right.$ foliar spray of $\mathrm{ZnSO}_{4} @ 0.4 \%+$ $\mathrm{CuSO}_{4} @ 0.2 \%+$ Boric acid @0.2\%(2 sprays at just before flowering and marble stage)] followed by $\mathrm{T}_{8}\left(242.33 \mathrm{~kg} \mathrm{plant}^{-1}\right)$ and $\mathrm{T}_{10}\left(232.30 \mathrm{~kg}\right.$ plant $\left.^{-1}\right)$. The lower yield tree ${ }^{-1}$ $\left(168.90 \mathrm{~kg} \mathrm{plant}{ }^{-1}\right)$ was recorded in $\mathrm{T}_{1}$ [Control (RDF)] followed by $\mathrm{T}_{6}(202.42 \mathrm{~kg}$ plant $\left.^{-1}\right)$ and $\mathrm{T}_{7}\left(217.15 \mathrm{~kg}\right.$ plant $\left.^{-1}\right)$. The significant variation was also found with respect to fruit yield hectare ${ }^{-1}$ and it was ranged from 16890 to $26417 \mathrm{~kg} \mathrm{ha}^{-1}$. The maximum fruit yield hectare ${ }^{-1}\left(26417 \mathrm{~kg} \mathrm{ha}^{-1}\right)$ was recorded with the application of $\mathrm{T}_{5}$ followed by $\mathrm{T}_{8}\left(24233 \mathrm{~kg} \mathrm{ha}^{-1}\right)$ and $\mathrm{T}_{10}(23230$ $\left.\mathrm{kg} \mathrm{ha}^{-1}\right)$. The minimum fruit yield per hectare $\left(16890 \mathrm{~kg} \mathrm{ha}^{-1}\right)$ was obtained with the application of $T_{1}$. The significant increase in fruit yield is a cumulative effect of increase in number of fruits because of reduction in fruit drop and also might be due to application of micronutrient that may influence the physiological processes resulting into higher fruit set and production of mango. The results are in conformity with the findings of Dutta and Dhua (2002), Singh et al., (2003), Gaya et al., (2008) and Gurjar et al., (2015) in mango.

\section{Yield efficiency and per cent increase in} yield

The data recorded on yield efficiency and per cent increase in yield are presented in Table 2. The data revealed that the yield efficiency showed non-significant results, ranged from 0.465 to $0.551 \mathrm{~kg} \mathrm{~m}^{-3}$. The maximum yield efficiency $\left(0.551 \mathrm{~kg} \mathrm{~m}^{-3}\right)$ was obtained with the application of $\mathrm{T}_{5}[\mathrm{RDF}+$ foliar spray of $\mathrm{ZnSO}_{4} @ 0.4 \%+\mathrm{CuSO}_{4} @ 0.2 \%+$ Boric acid @ $0.2 \%$ (2 sprays at just before flowering and marble stage)] followed by $\mathrm{T}_{8}$ $\left(0.548 \mathrm{~kg} \mathrm{~m}^{-3}\right)$ and $\mathrm{T}_{4}\left(0.537 \mathrm{~kg} \mathrm{~m}^{-3}\right)$. The minimum yield efficiency $\left(0.465 \mathrm{~kg} \mathrm{~m}^{-3}\right)$ was obtained with the application of $\mathrm{T}_{1}$ [Control RDF)]. The results recorded on per cent increase in yield revealed the variations with treatment combinations of inorganic manure, micronutrients and sea weed sap. The data showed that the maximum per cent increase in yield $(56.40 \%)$ was obtained with the application of $\mathrm{T}_{5}$ followed by $\mathrm{T}_{8}(43.45 \%)$ and $\mathrm{T}_{10}(37.52 \%)$, over the control.

\section{Effect of micronutrients and sea weed sap on physical quality parameters}

\section{Fruit weight, fruit size (length and width)}

It is apparent from the data presented in Table 3 that all the treatments were differed significantly in their fruit weight. The wide range of fruit weight 164.86 to $221.98 \mathrm{~g}$ was observed with various treatments under study. The maximum fruit weight $(221.98 \mathrm{~g})$ was recorded in $\mathrm{T}_{10}[\mathrm{RDF}+10 \%$ Sea weed sap (2 sprays at panicle emergence and marble stage) + $\mathrm{ZnSO}_{4} @ 200 \mathrm{~g}+\mathrm{CuSO}_{4} @ 100 \mathrm{~g}+$ Boric acid@100 g (soil application) in basin after harvest] which was statistically at par with $\mathrm{T}_{9}$ $(216.98 \mathrm{~g})$, whereas, the minimum fruit weight $(164.86 \mathrm{~g})$ was recorded with $\mathrm{T}_{1}$ [Control (RDF)]. The mean values for fruit length under different treatments varied from 8.16 $\mathrm{cm}$ to $10.87 \mathrm{~cm}$. The maximum fruit length $(10.87 \mathrm{~cm})$ was recorded in $\mathrm{T}_{10}$ which was statistically at par with $\mathrm{T}_{9}(10.49 \mathrm{~cm})$, whereas, the minimum fruit length $(8.16 \mathrm{~cm})$ was observed with $T_{1}$. A perusal of observation on the fruit width also revealed the significant variation among trees of various treatments. The mean values of fruit 
width showed a range of $5.44 \mathrm{~cm}$ to $6.54 \mathrm{~cm}$. The maximum fruit width $(6.54 \mathrm{~cm})$ was recorded in $\mathrm{T}_{10}$ which was statistically at par with $\mathrm{T}_{9}(6.52 \mathrm{~cm})$, whereas, the minimum fruit width $(5.44 \mathrm{~cm})$ was recorded with $\mathrm{T}_{1}$. The increase in fruit weight might be due to increased cell division and expansion. Appreciable improvement in fruit weight, fruit length and fruit diameter by sea weed sap application has also been reported by Chawdhury et al., (2007), Karim et al., (2008) and Ahmed et al., (2014) in mango.

\section{Effect of micronutrients and sea weed sap on chemical quality parameters}

\section{Total soluble solids, titratable acidity and total sugars}

The critical examination of the data indicated the presence of significant variation for total soluble solids (T.S.S) content with various treatments under study (Table 3 and Fig. 1). The mean values of T.S.S content ranged from 16.21 to $18.51{ }^{\circ} \mathrm{B}$. Among all the treatments, $\mathrm{T}_{5}\left[\mathrm{RDF}+\right.$ foliar spray of $\mathrm{ZnSO}_{4} @ 0.4 \%+$ $\mathrm{CuSO}_{4} @ 0.2 \%+$ Boric acid @ $0.2 \%$ (2 sprays at just before flowering and marble stage)] possessed the higher amount of total soluble solids $\left(18.51{ }^{\circ} \mathrm{B}\right)$ followed by $\mathrm{T}_{8}$ $\left(18.30{ }^{\circ} \mathrm{B}\right)$, however, these values were statistically at par with each other. The lower content $\left(16.21^{\circ} \mathrm{B}\right)$ of total soluble solids was found in $\mathrm{T}_{1}$ [Control RDF)]. The enhancement in quality of fruit could be due to the catalytic action of micronutrients. Hence, the foliar applications of micronutrients quickly increase the uptake of macronutrients in the tissues and organs of the plant and decrease the nutritional deficiencies that finally lead to improvement in the fruit quality. In the conducted trial, the maximum titratable acidity $(0.309 \%)$ was observed in $\mathrm{T}_{1}$ [Control (RDF)] which was followed by $\mathrm{T}_{6}(0.285 \%)$ and $\mathrm{T}_{7}(0.269 \%)$, whereas, the minimum acidity $(0.149 \%)$ was found in $\mathrm{T}_{5}\left[\mathrm{RDF}+\right.$ foliar spray of $\mathrm{ZnSO}_{4} @$
$0.4 \%+\mathrm{CuSO}_{4} @ 0.2 \%+$ Boric acid @ 0.2 $\%$ (2 sprays at just before flowering and marble stage)].

Lower acidity in the fruits results due to higher accumulation of sugars, better translocation of sugars into fruit tissues and conversion of organic acids into sugars. Similar findings were also observed by Beniwal et al., (1992) in grapes and it was also suggested that the rapid utilization of organic acid in respiration at senescence stage of fruits or delayed ripening might have another possible reasons responsible for minimizing the titratable acidity (Goswami et al., 2012). Present results regarding TSS and acidity are in accordance with the findings of Singh et al., (2003), Dutta et al., (2004), Gaya et al., (2008) and Anees et al., (2011) in mango.

It is clear from the data presented in Table 3 that the total sugars were found significantly varying with various treatments under study. The higher total sugar content $(12.88 \%)$ was recorded in $\mathrm{T}_{5}\left[\mathrm{RDF}+\right.$ foliar spray of $\mathrm{ZnSO}_{4}$ @0.4\%+. $\mathrm{CuSO}_{4} @ 0.2 \%+$ Boric acid @ $0.2 \%$ (2 sprays at just before flowering and marble stage)]which was found statistically at par with $\mathrm{T}_{8}(12.34 \%), \mathrm{T}_{4}(12.01 \%), \mathrm{T}_{9}(11.45$ $\%$ ) and $\mathrm{T}_{10}(11.34 \%)$, whereas, the lower total sugar content $(10.62 \%)$ was observed in $\mathrm{T}_{1}$ [Control (RDF)]. The initial rise in sugar content of fruits might be due to conversion of starch into sugar while decreasing trend of sugar under higher doses of chemicals might be due to consumption of more sugar for respiration during storage. The higher percentage of total sugar might be due to efficient translocation of photosynthates to the fruits by regulation of zinc substances. These results are in agreement with the findings of Dutta and Banik (2007) in guava, Samant et al., (2008) in ber and Goswami et al., (2012) in guava. 
Table.1 Treatment details of micronutrient and sea weed sap application on mango cv. Dashehari

\begin{tabular}{|c|c|}
\hline $\begin{array}{c}\text { Treatment } \\
\text { symbol }\end{array}$ & Treatment details \\
\hline $\mathbf{T}_{1}$ & Control (RDF) \\
\hline $\mathbf{T}_{2}$ & $\begin{array}{l}\mathrm{RDF}+\mathrm{ZnSO}_{4} @ 200 \mathrm{~g}+\text { Boric acid @ } 100 \mathrm{~g} \text { (soil application) in basin } \\
\text { after harvest }\end{array}$ \\
\hline $\mathbf{T}_{3}$ & $\begin{array}{l}\mathrm{RDF}+\mathrm{ZnSO}_{4} @ 200 \mathrm{~g}+\mathrm{CuSO}_{4} @ 100 \mathrm{~g}+\text { Boric acid @ } 100 \mathrm{~g} \text { (soil } \\
\text { application) in basin after harvest }\end{array}$ \\
\hline $\mathbf{T}_{4}$ & $\begin{array}{l}\mathrm{RDF}+\text { foliar spray of } \mathrm{ZnSO}_{4} @ 0.4 \%+\text { Boric acid @ } 0.2 \% \text { (2 sprays at } \\
\text { just before flowering and marble stage) }\end{array}$ \\
\hline $\mathbf{T}_{5}$ & $\begin{array}{l}\mathrm{RDF}+\text { foliar spray of } \mathrm{ZnSO}_{4} @ 0.4 \%+\mathrm{CuSO}_{4} @ 0.2 \%+\text { Boric Acid @ } \\
0.2 \% \text { (2 sprays at just before flowering and marble stage) }\end{array}$ \\
\hline $\mathbf{T}_{6}$ & $\begin{array}{l}\mathrm{RDF}+\mathrm{ZnSO}_{4} @ 100 \mathrm{~g}+\mathrm{CuSO}_{4} @ 50 \mathrm{~g}+\text { Boric acid @ } 50 \mathrm{~g} \text { (soil } \\
\text { application) in basin after harvest + foliar spray of } \mathrm{ZnSO}_{4} @ 0.2 \%+\text { Boric } \\
\text { acid @ } 0.1 \% \text { ( } 2 \text { sprays at just before flowering and marble stage) }\end{array}$ \\
\hline $\mathbf{T}_{7}$ & $\begin{array}{l}\mathrm{RDF}+\mathrm{ZnSO}_{4} @ 100 \mathrm{~g}+\mathrm{CuSO}_{4} @ 50 \mathrm{~g}+\text { Boric acid @ } 50 \mathrm{~g} \text { (soil } \\
\text { application) in basin after harvest }+ \text { foliar spray of } \mathrm{ZnSO}_{4} @ 0.2 \%+ \\
\mathrm{CuSO}_{4} @ 0.1 \%+\text { Boric acid @ } 0.1 \% \text { ( } 2 \text { sprays at just before flowering } \\
\text { and marble stage) }\end{array}$ \\
\hline $\mathbf{T}_{8}$ & $\begin{array}{l}\text { RDF + IIHR Mango Special* @ } 5 \mathrm{~g} / \mathrm{l} \text { ( } 2 \text { sprays at two months before } \\
\text { flowering and marble stage) }\end{array}$ \\
\hline $\mathbf{T}_{9}$ & $\begin{array}{l}\mathrm{RDF}+10 \% \text { Sea weed sap** ( } 2 \text { sprays at panicle emergence and marble } \\
\text { stage) }\end{array}$ \\
\hline$T_{10}$ & $\begin{array}{l}\mathrm{RDF}+10 \% \text { Sea weed sap** }(2 \text { sprays at panicle emergence and marble } \\
\text { stage })+\mathrm{ZnSO}_{4} @ 200 \mathrm{~g}+\mathrm{CuSO}_{4} @ 100 \mathrm{~g}+\text { Boric acid @ } 100 \mathrm{~g} \text { (soil } \\
\text { application) in basin after harvest }\end{array}$ \\
\hline
\end{tabular}

Note: RDF:Recommended dose of fertilizers (1000 g N: 750 g P: 1000 g K); **Sea weed sap: Kappaphycus spp.; *IIHR Mango Special composition (Zn-0.2 \%, Fe-0.2 \%, Cu-1 \%, Mn-1\%, B-0.75\% and Mg-1 \%) 
Table.2 Effect of micronutrients and sea weed sap on number of fruits and yield attributes of mango cv. Dashehari

\begin{tabular}{|c|c|c|c|c|c|c|}
\hline \multirow[t]{2}{*}{$\begin{array}{c}\text { Treatments } \\
\#\end{array}$} & \multicolumn{2}{|c|}{$\begin{array}{l}\text { Number of fruit set } \\
\text { per panicle }\end{array}$} & \multicolumn{4}{|c|}{ Yield attributes } \\
\hline & $\begin{array}{c}\text { At pea } \\
\text { stage }\end{array}$ & $\begin{array}{c}\text { At } \\
\text { marble } \\
\text { stage }\end{array}$ & $\underset{{ }_{1}(\mathrm{~kg})}{\text { Yield plant }^{-}}$ & $\underset{{ }_{(\mathbf{k g})}}{\text { Yield ha }^{-}}$ & $\begin{array}{l}\text { Per cent } \\
\text { increase in } \\
\text { yield over the } \\
\text { control }\end{array}$ & $\begin{array}{c}\text { Yield } \\
\text { efficiency } \\
\left(\mathrm{kg} \mathrm{m}^{-3}\right)\end{array}$ \\
\hline $\mathrm{T}_{1}$ & 6.75 & 1.91 & 168.90 & 16890 & 0.00 & 0.465 \\
\hline $\mathrm{T}_{2}$ & 8.00 & 2.33 & 218.65 & 21865 & 29.44 & 0.495 \\
\hline $\mathrm{T}_{3}$ & 8.37 & 2.66 & 222.40 & 22240 & 31.66 & 0.530 \\
\hline $\mathrm{T}_{4}$ & 8.57 & 3.16 & 227.76 & 22776 & 34.83 & 0.537 \\
\hline $\mathrm{T}_{5}$ & 9.67 & 4.58 & 264.17 & 26417 & 56.40 & 0.551 \\
\hline $\mathrm{T}_{6}$ & 7.99 & 3.06 & 202.42 & 20242 & 19.83 & 0.523 \\
\hline $\mathrm{T}_{7}$ & 8.66 & 3.30 & 217.15 & 21715 & 28.55 & 0.533 \\
\hline $\mathrm{T}_{8}$ & 8.98 & 3.83 & 242.33 & 24233 & 43.45 & 0.548 \\
\hline $\mathrm{T}_{9}$ & 8.75 & 3.58 & 221.43 & 22143 & 31.08 & 0.530 \\
\hline $\mathrm{T}_{10}$ & 8.83 & 3.75 & 232.30 & 23230 & 37.52 & 0.522 \\
\hline $\mathrm{CD}(5 \%)$ & 0.39 & 0.12 & 9.91 & 1090.36 & - & NS \\
\hline
\end{tabular}


Table.3 Effect of micronutrients and sea weed sap on physical and chemical quality parameters of mango cv. Dashehari

\begin{tabular}{|c|c|c|c|c|c|c|c|c|}
\hline \multirow[t]{3}{*}{ Treatments\# } & \multicolumn{3}{|c|}{ Physical quality parameters } & \multirow{2}{*}{\multicolumn{5}{|c|}{ Chemical quality parameters }} \\
\hline & \multirow{2}{*}{$\begin{array}{c}\text { Fruit } \\
\text { weight } \\
\text { (g) }\end{array}$} & \multicolumn{2}{|c|}{ Fruit size } & & & & & \\
\hline & & $\begin{array}{c}\text { Length } \\
\text { (cm) }\end{array}$ & $\begin{array}{c}\text { Width } \\
\text { (cm) }\end{array}$ & $\begin{array}{c}\text { TSS } \\
\left({ }^{0} \text { Brix }\right)\end{array}$ & $\begin{array}{c}\text { Titratable } \\
\text { acidity }(\%)\end{array}$ & $\begin{array}{c}\text { Total sugars } \\
(\%)\end{array}$ & $\begin{array}{c}\text { Ascorbic acid } \\
\text { content (mg } 100 \\
\mathrm{~g}^{-1} \text { pulp) }\end{array}$ & $\begin{array}{l}\text { Total carotenoids } \\
\text { content (mg } 100 \mathrm{~g}^{-1} \\
\text { pulp) }\end{array}$ \\
\hline $\mathbf{T}_{1}$ & 164.86 & 8.16 & 5.44 & 16.21 & 0.309 & 10.62 & 43.82 & 9.90 \\
\hline $\mathbf{T}_{2}$ & 169.89 & 8.69 & 5.56 & 16.44 & 0.245 & 11.44 & 39.60 & 9.98 \\
\hline $\mathbf{T}_{3}$ & 168.44 & 8.88 & 5.58 & 16.94 & 0.249 & 11.20 & 38.00 & 9.93 \\
\hline $\mathbf{T}_{4}$ & 170.53 & 9.51 & 5.79 & 17.38 & 0.236 & 12.01 & 36.80 & 10.03 \\
\hline $\mathbf{T}_{\mathbf{5}}$ & 186.25 & 9.82 & 5.80 & 18.51 & 0.149 & 12.88 & 43.62 & 10.09 \\
\hline $\mathbf{T}_{6}$ & 172.56 & 9.31 & 5.67 & 17.21 & 0.285 & 11.69 & 41.31 & 9.92 \\
\hline $\mathbf{T}_{7}$ & 178.66 & 9.46 & 5.84 & 16.88 & 0.269 & 10.91 & 38.00 & 9.27 \\
\hline $\mathbf{T}_{8}$ & 191.73 & 10.02 & 5.94 & 18.30 & 0.168 & 12.34 & 42.84 & 9.78 \\
\hline $\mathbf{T}_{9}$ & 216.98 & 10.49 & 6.52 & 16.98 & 0.175 & 11.45 & 43.32 & 9.98 \\
\hline $\mathbf{T}_{10}$ & 221.98 & 10.87 & 6.54 & 17.57 & 0.178 & 11.34 & 41.18 & 9.77 \\
\hline CD (5\%) & 8.90 & 0.46 & 0.23 & 0.75 & 0.91 & 0.16 & 1.93 & NS \\
\hline
\end{tabular}


Int.J.Curr.Microbiol.App.Sci (2018) 7(12): 397-406

Fig.1 Effect of micronutrients and sea weed sap on TSS and total sugar of mango cv. Dashehari.

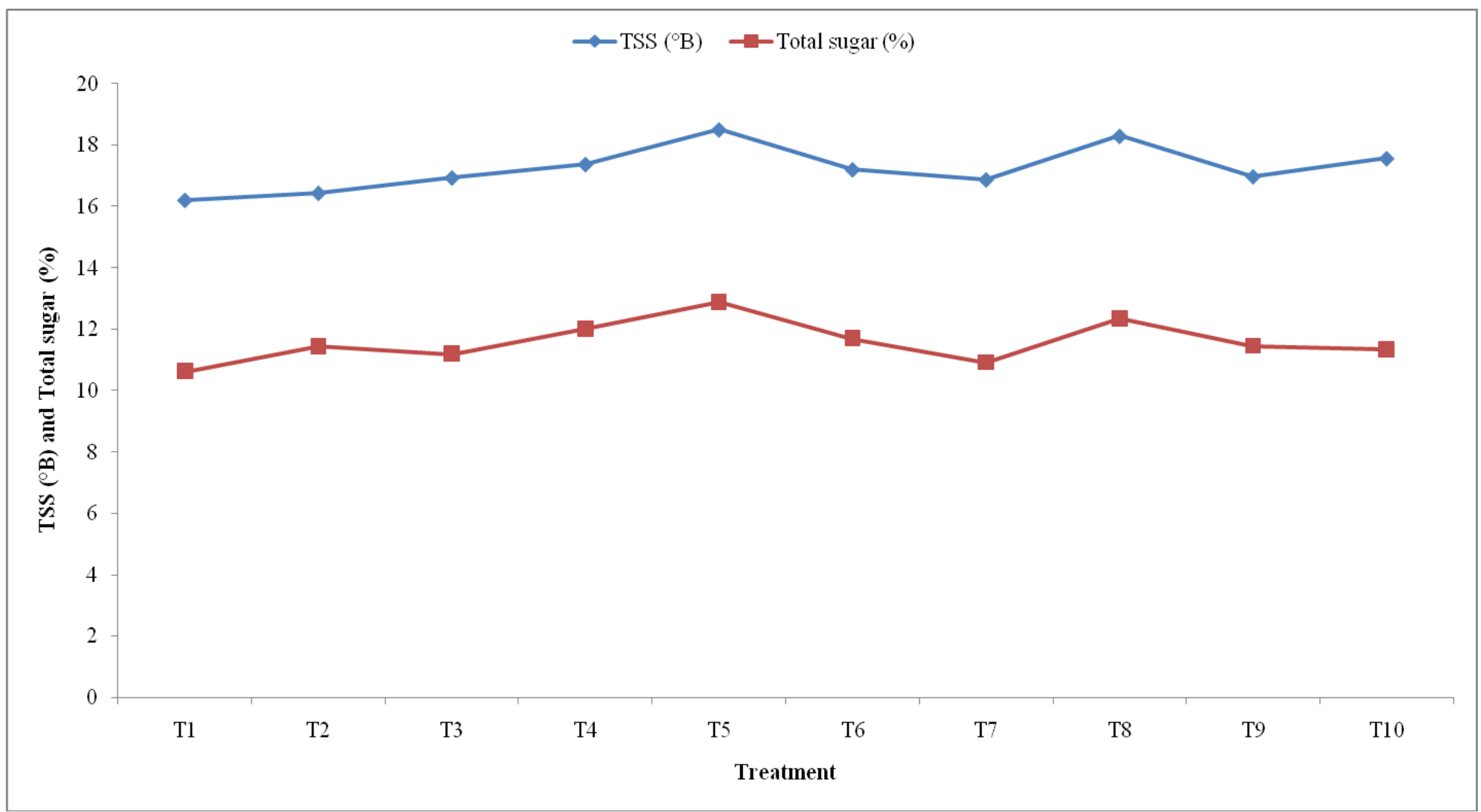




\section{Ascorbic acid and total carotenoids content}

The data on ascorbic acid and total carotenoids given in Table 3 revealed significant variation with the use of different treatments. The maximum ascorbic acid content (43.82 mg $100 \mathrm{~g}^{-1}$ ) was calculated with $\mathrm{T}_{1}$ [Control (RDF)] which was found statistically at par with $\mathrm{T}_{5}\left(43.62 \mathrm{mg} 100 \mathrm{~g}^{-1}\right)$, $\mathrm{T}_{9}$ (43.32 $\mathrm{mg} 100 \mathrm{~g}^{-1}$ ) and $\mathrm{T}_{8}(42.84 \mathrm{mg} 100$ $\left.\mathrm{g}^{-1}\right)$. The minimum ascorbic acid content (36.80 mg $100 \mathrm{~g}^{-1}$ ) was recorded with application of $\mathrm{T}_{4}[\mathrm{RDF}+$ foliar spray of $\mathrm{ZnSO}_{4} @ 0.4 \%+$ Boric acid @0.2\%(2 sprays at just before flowering and marble stage)].

As far as total carotenoids content is concerned, the mean values showed that the different treatments were not able to affect the total carotenoids content. The mean value for this parameter exhibited a range of 9.27 to $10.09 \mathrm{mg} 100 \mathrm{~g}^{-1}$. In the present trial, maximum total carotenoids content $(10.09 \mathrm{mg}$ $100 \mathrm{~g}^{-1}$ ) was observed in $\mathrm{T}_{5}[\mathrm{RDF}+$ foliar spray of $\mathrm{ZnSO}_{4} @ 0.4 \%+\mathrm{CuSO}_{4} @ 0.2 \%+$ Boric acid @ 0.2\% (2 sprays at just before flowering and marble stage]followed by $\mathrm{T}_{4}$ (10.03 mg $100 \mathrm{~g}^{-1}$ ), whereas, the minimum total carotenoids content $\left(9.27 \mathrm{mg} 100 \mathrm{~g}^{-1}\right)$ was found in $\mathrm{T}_{7}\left[\mathrm{RDF}+\mathrm{ZnSO}_{4} @ 100 \mathrm{~g}+\right.$ $\mathrm{CuSO}_{4} @ 50 \mathrm{~g}+$ Boric acid @ 50 g (soil application) in basin after harvest + foliar spray of $\mathrm{ZnSO}_{4} @ 0.2 \%+\mathrm{CuSO}_{4} @ 0.1 \%+$ Boric acid@0.1\%(2 sprays at just before flowering and marble stage)]. These results were supported by the findings of Hasan et al., (2013) in mango, Ali et al., (2014) in peach and Ghosh et al., (2014) in sweet orange.

Thus, it is concluded that the application of recommended dose of fertilizer (RDF) with foliar spray of micronutrients may be adopted for improving fruit set, yield and quality of mango cv. Dashehari.

\section{References}

Anonymous, 2017. Indian Horticulture Database. National Horticulture Board, Gurgaon,Haryana.

Abd El-Motty, Z.E., Shahin, M.F.M. and Hagagg, L.F. 2006. Response of Valencia oranges trees budded on Troyer citrange and Sour orange to foliar application of some macro and micro nutrients. J. Appl. Sci. Res., 2(11):952-965.

Ahmed. F.F., Kamel, M.K., Ibrahim, H.I.M. 2014. The synergistic effects of using plant extracts and salicylic acid on yield and fruit quality of Keitte mango trees. Stem Cell, 5: 30-39.

Ali, A., Perveen, S., Noor, S., Shah, M., Zhang, Z., Wahid, F., Shah, M., Bibi, S. and Majid, A. 2014. Effect of foliar application of micronutrients on fruit quality of peach. Amer. J. Plant Sci., 5: 1258-1264.

Anees, M., Tahir, F.M., Shahzad, J. and Mahmood, N. 2011. Effect of foliar application of micronutrients on the quality of mango (Mangifera indica L.) $\mathrm{cv}$. Dashehari fruit. Mycopath, 9(1): 25-28.

Beniwal, B.S., Gupta, O.P. and Ahlawat, V.P. 1992. Effect of foliar application of urea and potassium sulphate on physicochemical attributes of grapes (Vitis vinifera L.) cv. Perlette. Haryana J. Hort. Sci., 21(34): $161-165$.

Chawdhury, M.N.A., Rahim, M.A., Khalequzzaman, K.M., Humauan, M.R. and Alam, M.M. 2007. Effect of plant extracts and time of application on incidence of anthracnose, yield and quality of mango. Int. J. Sustain, Crop Prod., 2(5): 59-68.

Cochran, W. and Cox, G.M. 1983. Experimental Design, Asia Publishing House, Bombay, pp. 143-147.

Deshpande, S.B., Fehrenbacher, J.B. and Beavers, A.H. 1971. Mollisols of tarai region of Uttar Pradesh, Northern Indian. Morphol. and Mineral. Geoderma,6: 179.

Dutta, P. 2004. Effect of foliar boron application on panicle growth, fruit retention and physico-chemical characters of mango $\mathrm{cv}$. Himsagar. Indian J. Hort., 61: 265-266.

Dutta, P. and Banik, A.K. 2007. Effect of foliar feeding of nutrients and plant growth 
regulators on physico-chemical quality of Sardar guava grown in red and lateritic tract of West Bengal. Acta Hort., 63(10): 735.

Dutta, P. and Dhua. R.S. 2002. Improvement on fruit quality of Himsagar mango through application of zinc, iron and manganese. Hort. J., 15(2): 1-9.

Gaya, P. 2008. Effect of pre harvest foliar spray of nutrients on fruit quality and shelf life of mango cv. Dashehari. M.Sc. Thesis, G.B. Pant University of Agriculture \& Technology, Pantnagar, Uttarakhand, India.

Gomez, K.A. and Gomez, A.A. 1984. Statistical procedures for Agricultural Research. A Willey - Interscience Publication, New York.

Goswami, A.K., Shukla, H.S., Kumar, P. and Mishra, D.S. 2012. Effect of pre-harvest application of micronutrients on quality of guava cv. Sardar. Hort Flora Res. Spectrum, 1(1): 60-63.

Gurjar, T.D., Patel, N.L., Panchal, B. and Chaudhari, D. 2015. Effect of foliar spray of micronutrients on flowering and fruiting of Alphonso mango. The Bioscan, 10(3):1053-1056.

Hasan, M.A., Manna, M., Dutta, P., Bhattacharya, K., Mandal, S. and Banerjee, H. 2013. Integrated nutrient management improving fruit quality of mango cv. Himsagar. Acta Hort.,992: 167-172.

Karim, M.A. and Rahim, M.A. 2008. Effects of different plant extracts and chemicals on yield and quality of fruits of four mango varieties. J. Agrofor. Environ., 2: 113-117.

Mengel, K.E. and Kirkby, E.A. 1987. Principles of plant nutrition. International Potash Institute. pp. 70-85.

Mosa, El-Gleel, W.F.A., Abd El-Megeed, N.A. and Paszt, L.S. 2015. The effect of the foliar application of potassium, calcium, boron and humic acid on vegetative growth, fruit set, leaf mineral, yield and fruit quality of 'Anna' apple trees. Amer. J. Exp. Agri., 8(4): 224-234.

Popenoe, W. 1920. Manual of Tropical and Subtropical Fruits. Mc Millan, Hafner Press, New York, pp.79-160.

Raverkar, K.P., Pareek, N., Chandra, R., Chauhan, S., Zodape, S.T. and Ghosh, A. 2016. Impact of foliar application of seaweed saps on yield, nodulation and nutritional quality in green gram (Vigna radiata L.). Legume Res.,3305: 1-4.

Samant, D., Mishra, N.K., Singh, A.K. and Lal, R.L. 2008. Effect of micronutrient sprays on fruit yield and quality during storage in ber cv. Umran under ambient conditions. Indian J. Hort.,65(4): 399-404.

Singh, J. and Maurya, A.N. 2003. Effect of micronutrients on quality of fruits of mango (Mangifera indica L.) cv. Mallika. Prog. Agri., 3(1 \& 2): 92-94.

Solimanzadeh, A., Mozafari, V., Pour, A.T. and Akhgar, A. 2013. Effect of zinc, copper and iron foliar application on fruit set and some quantity characteristics of pistachio trees. South Western J. Hort. Bio. Environ., 4(1): 19-34.

Thompson, A.H. and Batjer, L.P. 1950. The effect of boron in germinating medium on pollen germination and pollen tube growth for several deciduous fruit trees. Proc. Amer. Soc. Hort.Sci., 56: 227 -230.

Vavilov, N.I. 1926. The origin, variation, immunity and breeding of cultivated plants. Chronica Botanica,13(16): 1949-1950.

\section{How to cite this article:}

Ravina Pawar and Singh, A.K. 2018. Effect of Micronutrients and Sea Weed Sap on Fruit Set, Yield and Quality of Mango (Mangifera indica L.) cv. Dashehari. Int.J.Curr.Microbiol.App.Sci. 7(12): 397-406. doi: https://doi.org/10.20546/ijcmas.2018.712.050 